\title{
Ендотеліальна дисфункція при COVID-19 (огляд літератури)
}

\author{
А.І. Пак, О.О. Шевчук, С.М. Палій, Б.П. Сельський, М.М. Корда \\ Тернопільський національний медичний університет імені І.Я. Горбачевського МОЗ України, Тернопіль, Україна
}

\begin{abstract}
Анотація. На сьогодні вже $\epsilon$ неодноразові підтвердження, що SARS-CoV-2 - вірус, який призвів до пандемії COVID-19 в усьому світі, причетний до розвитку або посилення вже наявної ендотеліальної дисфункції. Основним шляхом проникнення вірусу в організм людини є рецептори ангіотензинперетворювального ферменту-2, які експресуються в тому числі на ендотеліальних клітинах. Потрапивши у клітини хазяїна, SARS-CoV-2 стимулює процеси локального запалення, внаслідок якого починають інтенсивно виділятися цитокіни, які, в свою чергу, також чинять негативний вплив на ендотелій. Активовані «цитокіновим штормом» шляхи комплементу призводять до ще більшого синтезу цитокінів, а також посиленої продукції молекул адгезії. Запальний процес в ендотеліальних клітинах стимулює прокоагулянтні, протромботичні та антифібринолітичні фактори, які згубно впливають на процес згортання крові. Окрім цього, надмірний синтез вазоконстрикторних факторів, активований ендотелієм, сприяє гіперкоагулятивним процесам в організмі. У статті розглянуто основні механізми розвитку ендотеліальної дисфункції при COVID-19. Розуміння ланок патогенезу цієї патології дасть змогу виявити певні аспекти лікування та попередження ускладнень у хворих на COVID-19, що допоможе справитися з ускладненнями та високою смертністю при цьому захворюванні.
\end{abstract}

Ключові слова: COVID-19, ендотеліальна дисфункція, цитокіни, гемостаз.

\section{Ендотелій: функціональні властивості та його дисфункція}

Ендотелій - суцільний одношаровий плоский епітелій мезенхімального походження, який вистилає внутрішню стінку усіх судин, регулює низку показників крові та забезпечує функцію кровоносних судин. Основні його функції - підтримання антикоагулянтних, антитромботичних та фібринолітичних властивостей крові. Ендотеліальні клітини забезпечують реактивність судин за допомогою речовин, які звужують судини (ендотелін-1, ангіотензинперетворювальний фермент (АПФ), ендопероксиди, ангіотензин II, уротензин II, простагландини $\mathrm{G}_{2}$ і $\mathrm{H}_{2^{\prime}}$ тромбоксан A $_{2}$, серотонін, арахідонова кислота, тромбін) та тих, які їх розширюють (оксид азоту (NO), простациклін, брадикінін, гістамін, ацетилхолін, серотонін, ендотелійпохідний гіперполяризуючий фактор, субстанція Р, натрійуретичний С-пептид) [1-4].

Основною речовиною, яка забезпечує вазодилатацію, $\epsilon$ NO. Крім цієї функції, він виконує ряд інших, зокрема знижує адгезію тромбоцитів та лейкоцитів, запобігає проліферації гладких м'язів, знижує виділення прозапальних цитокінів, протидіє окисненню ліпопротеїдів низької щільності та холестерину. Місцем утворення NO в організмі людини $\epsilon$ ендотеліальні клітини [2]. Синтез NO відбувається за допомогою ферменту NO-синтази та ряду коферментів, до яких входять флавінмононуклеотид, флавінаденіндинуклеотид, гем та тетрагідробіоптерин. Субстратами $\epsilon$ L-аргінін, кисень і нікотинамідаденіндинуклеотидфосфат (НАДФН), а кінцевими продуктами - L-цитрулін та NO [5].

NO-синтаза існує у трьох формах, а саме: ендотеліальна, індуцибельна та нейрональна [5]. Синтез ендотеліальної NO-синтази відбувається постійно, незалежно від будь-яких чинників, а ії активація здійснюється під впливом кальцій-кальмодулінового комплексу та підвищеної концентрації іонів Са в цитоплазмі ендотеліоцитів [2]. Посилювати активність NO-синтази можуть пептиди, включаючи рецептори, зв'язані з фосфоліпазою С в ендотеліальній клітині, та ендотеліальні фактори росту, такі як фактор росту фібробластів (fibroblast growth factor - FGF) та фактор росту судинного ендотелію (vascular endothelial growth factor VEGF) [6]. Концентрація ендотеліальної NO-синтази знижується при запаленні, гіпоксії, ендотеліальній дисфункції, що призводить до зниження рівня NO [7].

Активація індуцибельної NO-синтази у макрофагах та інших клітинах, наприклад адипоцитах, може спричиняти інтенсивне вивільнення NO i, як наслідок, розширення судин та зниження артеріального тиску. Припускають, що при респіраторній гіпоксії NO, отриманий під дією індуцибельної NO-синтази, може згубно впливати, зумовлюючи перекисне окиснення ліпідів та апоптоз клітин $[7,8]$.

NO, який синтезується із L-аргініну під дією ферменту NOсинтази, активує гуанілатциклазу у гладком'язових клітинах, яка, в свою чергу, стимулює утворення циклічного гуанозинмонофосфату (ц-ГМФ) [9]. Останній активує дві специфічні цГМФзалежні протеїнкінази (PKG I та PKG II), з яких PKG I забезпечує вазодилатацію та інгібує агрегацію тромбоцитів [10].

Однією 3 найважливіших судинозвужувальних речовин, яка виділяється ендотеліальними клітинами, $\epsilon$ ендотелін-1. Дію ендотеліну на гладком'язові клітини забезпечують рецептори, які розташовані на ендотелії $[2,3]$. $\mathrm{ET}_{\mathrm{A}}$-рецептори переважають у гладком'язових клітинах і відсутні в ендотеліальних клітинах. Взаємодія ендотеліну-1 з ними викликає стійку вазоконстрикцію і проліферацію гладком'язових клітин. Більша частина $\mathrm{ET}_{\text {в- }}$ рецепторів розташована в мембрані ендотеліальних клітин, хоча

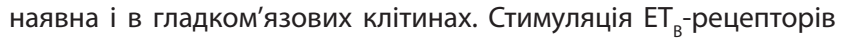
сприяє утворенню NO і простацикліну, які викликають розширення судин, в той час як частина $\mathrm{ET}_{\text {в }}$-рецепторів, що розташовані на гладком'язових клітинах, спричиняють вазоконстрикцію. Таким чином, вплив ендотеліну-1 на звуження і розширення судин визначається локалізацією рецепторів і балансом між $\mathrm{ET}_{\mathrm{A}}$ - $\mathrm{i}$ $\mathrm{ET}_{\text {B }}$-рецепторами [11].

Порушення ендотеліальної функції належить до системного стану, при якому ендотелій втрачає свої фізіологічні властивості [12]. Ендотеліальна дисфункція може викликатися багатьма чинниками (наприклад цукровий діабет, метаболічний синдром, артеріальна гіпертензія, шкідливі звички, відсутність фізичної активності, захворювання периферичних судин, хронічна ниркова недостатність, тяжкі вірусні інфекції [13]. Важливим фактором ендотеліальної дисфункції $\epsilon$ ожиріння. Гормон лептин, який циркулює у надмірній кількості в осіб з ожирінням, зумовлює розвиток ендотеліальної дисфункції. Він призводить до зниженого синтезу NO та збільшеної кількості моноцитарного хемотаксичного протеїну-1 (monocyte chemoattractant protein $1-$ MCР-1), що, у свою чергу, впливає не тільки на вазоконстрикцію, а й на посилену інфільтрацію лейкоцитів на судинній стінці $[8,14]$. Також відомо, що у пацієнтів із серцево-судинними захворюваннями та гіперхолестеринемією, гіпертригліцеридемією, цукровим діабетом 2-го типу, нирковою недостатністю і кардіальним синдромом наявна висока концентрація циркулюючого асиметричного диметиларгініну (asymmetric dimethylarginine ADMA), який $\epsilon$ аналогом L-аргініну і призводить до зниження активності NO-синтази i, як наслідок, до зниження рівня NO. 
Це дозволяє зрозуміти ще одну з причин ендотеліальної дисфункції $[15,16]$.

\section{Проникнення SARS-}

\section{CoV-2 в організм людини}

SARS-CoV-2 належить до сімейства Coronaviridae, яке включає такі віруси, як SARS-CoV та MERS-CoV, що спричиняли масштабні спалахи тяжких респіраторних інфекцій [17]. Коронавіруси класифікують на такі основні роди, як $\alpha, \beta$, $\delta$ та ү. SARS-CoV-2, який спричинив пандемію COVID-19, належить до $\beta$-роду [18]. Вперше спалах коронавірусної інфекції виявлено у грудні 2019 р. в Ухані, Китай, де зафіксували перші випадки тяжкої пневмонії [19]. Згодом вірус поширився. Стрімке зростання кількості заражень COVID-19 в усьому світі призвело до того, що 11.03.2020 p. Всесвітня організація охорони здоров'я оголосила пандемію [20]. За даними Університету Джона Хопкінса (Johns Hopkins University), станом на 17.06.2021р. зареєстровано 177120609 підтверджених випадків COVID-19, з яких 3834951 летальні [21].

SARS-CoV-2 здатний швидко поширюватися серед великого скупчення людей та передається від людини до людини повітряно-крапельним шляхом. Вірус залишається життєздатним від 2 год до 14 днів, залежно від погодних умов та предметів, на які він потрапив [19].

Рецептором для вірусу SARS-CoV-2 $€$ АПФ-2, що розміщується на мембранах ендотеліальних та інших клітин, і це забезпечує його проникнення у клітини різних органів. Спорідненість спайкового білка SARS-CoV-2 до АПФ-2 значно вища порівняно з SARS-CoV, що забезпечує кращу проникність SARS-CoV-2 у клітини та вищий рівень зараження ним [18]. Z. Varga та співавтори (2020) продемонстрували наявність SARS-CoV-2 в ендотеліальних клітинах різних органів, що вказує на тісний взаємозв'язок між ендотелієм, АПФ-2 та COVID-19 [22]. Хоча АПФ-2 $є$ основним рецептором для проникнення вірусу, відомо, що існують так звані альтернативні шляхи проникнення SARS-CoV-2 в організм людини [23]. Ними виступають CD209L (L-SIGN), CD209 (DC-SIGN), рецептори сіалової кислоти, індуктор металопротеїнази позаклітинного матриксу CD147, клітинний рецептор нейропілін-1. Усі ці фактори підвищують вірулентність SARS-CoV-2 [12, 23-25].

Для проникнення в організм вірус на своїй поверхні має тример, поверхневий глікопротеїн, який відіграє важливу роль у прикріпленні вірусу, його злитті та проникненні всередину клітини $[23,26]$. Цей тример складається 3 двох субодиниць: S1 (рецепторна) та S2 (відповідає за злиття коронавірусу з мембраною) [27]. Субодиниця S1 розділяється на два домени N-кінцевий (S1-NTD) та C-кінцевий (S1-CTD), за допомогою якого вірус з'єднується з АПФ-2 на поверхні клітини, що забезпечує проникнення у клітину-хазяїна [28].

Після зв'язування SARS-CoV-2 з рецептором, для того, щоб відбулося повне злиття між мембранами клітини-хазяїна та вірусу, субодиниця S2 починає розщеплюватися протеазами, такими як трансмембранний білок серин-2 (TMPRSS2) та фурин [29]. Після того як SARS-CoV-2 проник у клітину-хазяїна, відбувається реплікація його вірусного геному РНК, що призводить до утворення нової РНК. Надалі новоутворені речовини перетворюються на віріонвмісні везикули, що зливаються з клітинною мембраною з метою подальшого виділення вірусу [27].

Існує думка, що можна застосовувати препарати, які інгібують TMPRSS2, тим самим блокуючи вхід вірусу у клітину [29]. Підтвердженням цієї гіпотези є експериментальне дослідження, яке проводили на мишах. Інгібуючи TMPRSS2, блокувалося потрапляння SARS-CoV-2 в організм та знижувалася тяжкість вірусної інфекції [30].

Інфіковані клітини піддаються піроптозу, що призводить до вивільнення молекулярних структур, які пов'язані з пошкодженням, і викликає продукцію прозапальних цитокінів та хемокінів. Як наслідок, це призводить до активації ендотеліальних клітин. Активований ендотелій посилює експресію фактора фон Віллебранда (von Willebrand factor - vWF) та молекул адгезії, включаючи молекулу міжклітинної адгезії (inter-cellular adhesion molecule 1 - ICAM-1), av $\beta 3$, Р- та Е-селектин, що, в свою чергу, призводить до активації тромбоцитів, лейкоцитів і комплементу [31].

\section{Роль рецепторів АПФ-2 у розвитку ендотеліальної дисфункції при COVID-19}

Рецептори АПФ-2 розташовані по всьому організму, найбільше їх скупчення відмічено в ендотеліальних клітинах артерій, вен, клітинах альвеолярного епітелію I та II типу легеневої тканини, в серці, кишечнику [22]. Виявлено білок нуклеокапсиду (N) SARS-CoV-2 в канальцях нирок, а також скупчення частинок вірусу в канальцевому епітелії та подоцитах [32]. Тому в осіб, які хворіють на COVID-19, досить часто виникає поліорганна дисфункція [22, 25, 33].

Під дією реніну ангіотензиноген розщеплюється й утворюється ангіотензин І. 3 ангіотензину I під впливом АПФ синтезується ангіотензин II, який $\epsilon$ потужним вазоконстриктором, активатором ендотелію та сприяє вивільненню цитокінів [18, 34]. Ангіотензин II може по-різному впливати на організм людини. Причиною цього $\epsilon$ те, що ангіотензин II служить лігандом для G-білкових рецепторів (GPCR). Активуючи AT1R, він зумовлює розвиток запальних реакцій, звуження і фіброзне ремоделювання судин. Стимуляція AT2R призводить до розширення судин та пригнічення їх росту [18]. Надалі новоутворений ангіотензин II під впливом АПФ та АПФ-2 перетворюється на ангіотензин III (Ang 1-7) [18, 27].

Вищезгаданий ангіотензин I (Ang 1-10) має й інший шлях перетворення. Під дією АПФ-2 він перетворюється на ангіотензин (Ang 1-9), який виконує ту саму функцію, що й ангіотензин III (Ang 1-7) [18]. Разом вони зв'язуються з GPCR, рецептором MasR та забезпечують вазодилататорну, антифібротичну та протизапальну функцію шляхом активації фосфоліпази А з утворенням арахідонової кислоти та фосфоїнозитид-3-кінази, яка стимулює ендотеліальну NO-синтазу [18]. За допомогою фосфорилювання та активації фосфоліпази С вони також стимулюють виділення внутрішньоклітинного кальцію [18].

Висока спорідненість SARS-CoV-2 до АПФ-2-рецептора може призвести до дисфункції ренін-ангіотензин-альдостеронової системи (РААС). Відомо, що РААС відповідає за такі важливі гомеостатичні процеси, як баланс електролітів та рідини, артеріальний тиск та проникність судин [35]. Все це пояснює низку ускладнень, які виникають при COVID-19.

Отже, АПФ-2 бере участь у зворотній регуляції РААС, протидіючи АПФ. Надлишок продукції АПФ-залежного ангіотензину II призводить до надмірної судинозвужувальної дії, а також посилення прозапального та прооксидативного впливу на судинну систему пацієнта. Індукований COVID-19 дисбаланс АПФ/АПФ-2 також викликає так зване явище «випадіння» АПФ на легенево-судинному рівні, з часом посилюючи місцеве запалення, прокоагулянтний стан та, ймовірно, підвищуючи сприйнятливість до SARS-CoV-2 у різних тканинах [7].

Ангіотензин II у надмірній кількості також може впливати на розвиток чи посилювати уже наявну ендотеліальну дисфункцію шляхом посиленого вироблення АФК. Ангіотензин II виступає в ролі прооксидантного пептиду, який за допомогою активації НАДФН-оксидаз у різних типах клітин, включаючи ендотеліоцити, підвищує синтез супероксид-аніонів. Внаслідок цього виникає надмірне споживання кисню та енергії. У нормальних умовах супероксиддисмутаза каталізує супероксидний аніон і перетворює його в $\mathrm{H}_{2} \mathrm{O}_{2}$, але при його надмірному утворенні під дією ангіотензину II значна кількість $\mathrm{H}_{2} \mathrm{O}_{2}$ реагує із NO. Це призводить до утворення пероксинітриту, i, як наслідок, до подальшого пошкодження клітин [27].

АПФ-2 забезпечує активацію тканинного активатора плазміногену (tissue plasminogen activator - tPA), при цьому спостерігаються профібринолітичні властивості ендотелію. На противагу надмірний синтез ангіотензину II та активація рецептора ангіотензину 1 (AT1R) призводять до утворення та вивільнення у великій кількості інгібітора активатора плазміногену-1 (РАІ-1) 
3 клітин ендотелію та гладких м'язів, цим самим забезпечуються протромботичний та антифібринолітичний ефекти. Враховуючи вищезазначене, можна узагальнити, що інгібування РАAC може бути корисним для запобігання утворенню тромбів [36].

Змінені функції АПФ та АПФ-2 також призводять до активації тромбоцитів. АПФ розщеплює брадикінін до таких метаболітів, як вазоактивний брадикінін та дез-Arg9-брадикінін, які надалі розщеплюються під дією АПФ-2. При блокуванні АПФ-2 відбувається накопичення дез-Arg9-брадикініну, під дією якого активуються як нейтрофіли, так і тромбоцити. Активовані тромбоцити прикріплюються до ендотеліальної стінки значно швидше. Відзначено, що у пацієнтів із COVID-19 відмічена підвищена міцність згустків, що відіграє важливу роль у розвитку та тяжкості тромбозу [17].

Симптоми в осіб, які мають супутню патологію (захворювання серцево-судинної системи, гіпертонічна хвороба, цукровий діабет, ожиріння, захворювання дихальної системи), пацієнтів старшого віку, курців, є тяжчими [8, 22, 37, 38]. Поряд $з$ іншими причинами це пов'язано також зі зниженим рівнем АПФ-2 та розвитком дисбалансу АПФ/АПФ-2 при COVID-19 [39].

$\epsilon$ дані, які вказують, що SARS-CoV-2 може опосередковано, через знижену регуляцію АПФ в міокарді, впливати на наявні запальні процеси та його пошкодження [40]. У хворих із COVID-19 відмічається відхилення таких лабораторних показників, як тропоніни та мозковий натрійуретичний пептид (brain natriuretic peptide - BNP), що є чітким підтвердженням ураження серцево-судинної системи [41].

Відомо, що інгібітори АПФ покращують функцію ендотелію, тому припускають, що при їх застосуванні симптоми SARS-CoV-2 будуть менш тяжкими [39].

Цікаво, що ген АПФ-2у людини знаходиться в ділянці Х-хромосоми (Хр22). Ці докази дійсно важливі, оскільки жінки, схоже, більше захищені від інфекції SARS-CoV-2, аніж чоловіки. Хоча механізми, що лежать в основі гендерної толерантності, досі невідомі, локалізація АПФ-2 в Х-хромосомі може бути ключовою. Цілком можливо, що друга Х-хромосома захищає жінок від поліморфізмів, які роблять інфекцію більш агресивною [42].

\section{Вплив цитокінів на розвиток ендотеліальної дисфункції при COVID-19}

Ендотелій відіграє важливу роль у регуляції запалення та імунітету за допомогою таких речовин, як інтерлейкін (interleukin IL)-1, -6, хемокіни, адгезивні молекули (VCAM-1 - молекули адгезії судинних клітин, ІСАМ - молекули міжклітинної адгезії, молекули адгезії лейкоцитів), Е- та Р-селектин, антигени гістосумісності. Ендотеліолоцити також виступають бар'єром проникності, беруть участь в утворенні клітинного матриксу за допомогою колагену та протеогліканів [2-4, 43, 44].

Ендотелій відповідає за підтримку судинного гомеостазу шляхом збалансованого виділення аутокринних і паракринних молекул. В умовах, коли виникає дисфункція ендотеліального шару, баланс порушується [41]. При ураженні ендотеліоцитів підвищується проникність судинної стінки до високомолекулярних молекул крові, збільшується адгезія лейкоцитів, що пов'язано з появою Е-селектину, посилюються прокоагулянтні та знижуються антикоагулянтні властивості, що викликає тромбоутворення, підвищується синтез прозапальних цитокінів [45]. Е-селектин $\epsilon$ маркером ендотеліальної дисфункції. Синтез його відбувається на активованих ендотеліоцитах. Е-селектин полегшує адгезію лейкоцитів, а також сприяє посиленому утворенню ICAM-1 та VCAM-1 і їх міграції через ендотеліальний бар'єр [45].

Bipyc SARS-CoV-2 проникає в організм через нижні дихальні шляхи. У багатьох випадках розвивається пневмонія, причиною чого $\epsilon$ швидка реплікація вірусу та масивне вивільнення цитокінів [46]. У хворих із COVID-19 відмічають значне збільшення вмісту IL, фактора некрозу пухлини (tumor necrosis factor - TNF)-a, VEGF, які виконують імунорегулювальну дію. Цитокіни, особливо VEGF, спричиняють підвищення мікросудинної проникності [7, 47].
«Цитокіновий шторм» відмічали і при попередніх коронавірусних пневмоніях, таких як тяжкий гострий респіраторний синдром (severe acute respiratory syndrome - SARS) та близькосхідний респіраторний синдром (Middle East respiratory syndrome - MERS), однак у тяжких пацієнтів із COVID-19 має місце значно вищий рівень цитокінів, зокрема IL-6, ніж у хворих на SARS та MERS [7]. Як правило, така надмірна продукція цитокінів призводить до розвитку гострого респіраторного дистрес-синдрому.

IL-6 - один із основних прозапальних цитокінів, який виділяється ендотеліальними клітинами. Відомо, що одним із найважливіших його активаторів $\epsilon$ вірусна інфекція. Зв'язування IL-6 з рецепторами IL-6 (sIL-6R), які розташовані на ендотеліальних клітинах, призводить до підвищеної проникності судин, виділення інших цитокінів та активації комплементу C5а $[26,48]$. У хворих на COVID-19 існує тісний взаємозв'язок між рівнем IL-6 та тяжкістю захворювання [47].

Kрім IL-6, у пацієнтів із COVID-19 підвищені показники таких прозапальних цитокінів, як IL-1 $\beta$ та TNF-a, які спричиняють посилення прозапальних та протромботичних функцій ендотелію. Це призводить до порушення регуляції згортання крові. Стимулюючи проліферацію мегакаріоцитів, вони спричиняють тромбоцитоз у судинному руслі [7, 26, 49, 50]. Ендотеліальні клітини в легенях виділяють IL-2R, який при взаємодії із IL-2 може спричиняти набряк легень [26].

Цитокіни, які виділяються у надмірній кількості при коронавірусній інфекції, збільшують виділення печінкою білків гострої фази, включаючи фібриноген, тим самим потенціюють прокоагулянтний стан в організмі. Фібриноген - головний фактор, що визначає в'язкість крові, і повідомляється про його високі рівні при COVID-19 [7, 26, 49, 50]. Фібриноген також бере участь у розвитку ендотеліальної дисфункції, а саме забезпечує полегшення адгезії лейкоцитів [51, 52]. За допомогою взаємодії із ICAM-1, інтегрином aV $\beta 1$ та aV $\beta 3$, фібриноген зв'язується з ендотеліоцитами [51]. Виділення ICAM-1 ендотеліальними клітинами посилюється при дії прозапальних цитокінів, атеросклерозі. Активація ICAM-1 призводить до змін в структурі ендотелію, створюючи між клітинами проміжки. Окрім того, ICAM-1 безпосередньо сприяє запальним реакціям у стінці кровоносних судин, посилюючи активацію ендотеліальних клітин та утворення атеросклеротичних бляшок [52]. Вважається, що фібриноген та фрагмент D (продукт ранньої деградації фібрину), зв'язуючись із ICAM-1, призводять до вазоконстрикції. Можна припустити, що D-димер також може зв'язуватися з ICAM-1 і спричиняти підвищену вазоконстрикцію [53].

Активовані цитокінами ендотеліальні клітини регулюють виділення тромбомодуліну, який відіграє ключову роль у активності тромбіну. Стійка активація тромбіну, у свою чергу, стимулює тромбоцити та посилює запалення через поверхнево-активні речовини, які експресуються тромбоцитами і запальними клітинами [45].

Ще одним наслідком гіперпродукції цитокінів та хемокінів $\epsilon$ підвищена мобілізація макрофагів та активація нейтрофілів і моноцитів. Активовані нейтрофіли та моноцити прилипають до ендотеліальних клітин, вивільняють при цьому вільні радикали похідні кисню, тим самим спричиняють дисфункцію ендотелію або збільшують уже наявне пошкодження [7]. Також моноцити та інші активовані клітини здатні виділяти тканинний фактор та фосфатидилсерин на своїх поверхнях, ініціюючи згортання крові [49].

Активовані нейтрофіли для затримання патогенних мікроорганізмів синтезують нейтрофільні позаклітинні пастки (neutrophil extracellular traps - NET) [27, 39]. Виявлено їх збільшення у багатьох хворих із COVID-19. NET відіграють важливу роль в іммобілізації та знищенні патогенних мікроорганізмів, але при неналежному регулюванні вони можуть викликати дисфункцію ендотеліальних клітин, ще більше посилюючи запалення у судинній стінці. При внутрішньосудинному утворенні нейтрофільних пасток вони можуть потенціювати тромботичні ускладнення в мікро- та макросудинах шляхом інактивування ендогенних антикоагулянтів та активації тромбоцитів [27, 39]. NET також забезпечують протеолітичну активність 
нейтрофільних серинових протеаз, наприклад нейтрофільної еластази, яка погіршує функцію антикоагулянтів, таких як тромбомодулін, що вивільняється з ендотеліальних клітин [54].

У хворих на COVID-19 також виявлено високий рівень позаклітинного хроматину та гістонів, які чинять цитотоксичну дію на ендотеліоцити $[27,39]$.

\section{Роль комплементу у розвитку ендотеліальної дисфункції при COVID-19}

Активація системи комплементу - реакція імунної системи організму у відповідь на патогени. Однак необмежена активація комплементу зумовлює розвиток ендотеліальної дисфункції, гострого та хронічного запалення, внутрішньосудинної коагуляції та пошкодження клітин і в кінцевому результаті призводить до поліорганної недостатності. Система комплементу складається 3 >30 білків, організованих за трьома шляхами активації, класичним, лектиновим та альтернативним [55]. Як було показано раніше, в активації комплементу важливу роль також відіграє «цитокіновий шторм» $[26,48]$. У свою чергу, активовані шляхи комплементу призводять до посиленої продукції ендотеліальних цитокінів, а також підвищують експресію важливих молекул адгезії ендотелію, таких як P-, Е-селектин та vWF [56].

При активації комплементу індукується утворення NET, що, в свою чергу, призводить до підвищеної активності прокоагулянтів (наприклад тромбіну) [57].

С5a - потужний анафілатоксин, який синтезується при розщепленні С5 під дією С5-конвертази і бере участь у загостренні запальних реакцій [55]. С5а виступає як центральний білок комплементу, який забезпечує прозапальні реакції в організмі людини, а також активує нейтрофіли, макрофаги, моноцити. Внаслідокцього відбувається надмірне виділення гістонів та активних форм кисню, що спричиняє розвиток ендотеліальної дисфункції, сприяє запальним процесам та тромбозу $[55,58]$. Взаємодія між С5a та рецептором C5aR на ендотеліальних клітинах може спричинити підвищення продукції молекул адгезії, внаслідок чого стимулюється адгезія лейкоцитів та їх проходження в паренхіму органів $[55,58]$. Інший протромботичний механізм дії С5а відбувається за допомогою регуляції тканинного фактора та експресії PAl-1 ендотеліальними клітинами та моноцитами [59]. Цікаво, що активація комплементу може як сприяти згортанню, так і перешкоджати йому. Наприклад гепарансульфат - це протеоглікан, який виділяється при пошкодженні ендотеліальних клітин (як внаслідок дії комплементу С5а, так і в результаті незалежних механізмів) і зменшує вираженість місцевого запалення та пригнічує згортання крові [60].

C5b, як і С5a, синтезується при розщепленні С5 під дією С5конвертази. C5b також відіграє важливу роль у виникненні ендотеліальної дисфункції [55]. Відомо, що C5b бере участь в утворенні C5b-9, який відповідає за внутрішньоклітинний потік кальцію в епітеліальних та ендотеліальних клітинах, порушення якого призводить до пошкодження ендотелію $[55,58]$. Ще одним механізмом дії C5b-9 $€$ те, що він активує тромбоцити, внаслідок чого підвищуються секреція і виділення мікрочастинок із тромбоцитарних гранул, які мають прокоагулянтні властивості $[55,58]$.

У дослідженні С. Magro та співавторів (2020) у деяких пацієнтів із COVID-19 виявлено значне відкладання компонентів термінального комплементу C5b-9 (мембранно-атакуючий комплекс), C4d та асоційованої з манозою лектину серинової протеази-2 (mannose-binding lectin-associated serine protease 2) у мікросудинному руслі. Це може свідчити про те, що існує тісний взаємозв'язок між вірусним захворюванням, комплементом і розвитком ендотеліальної дисфункції [61].

У роботі A.M. Risitano та співавторів (2020), де досліджували мишей з дефіцитом C3, інфікованих SARS-CoV, виявлено значно менші прояви порушення функцій легеневої системи, ніж у нормальних мишей, інфікованих SARS-CoV. Це пов'язано з тим, що, незважаючи на еквівалентні вірусні навантаження, інфільтрація нейтрофілів та запальних моноцитів у легеневій тканині була меншою у мишей з дефіцитом С3. Рівень цитокінів та хемокінів був зниженим як в легенях, так і в сироватці крові. На основі цього можна зробити припущення, що інгібування С3 при SARSCoV-2 також може полегшити запальні реакції в легенях та знизити рівень прозапальних цитокінів. Показано, що інгібітор C3 AMY-101, який вже випробуваний на людях, забезпечує ранню блокаду комплементу. Іншим шляхом впливу на комплемент $\epsilon$ введення специфічних антитіл проти рецептора C5aR. У експериментальних дослідженнях на мишах, інфікованих MERS-CoV, виявлено, що його введення зменшувало пошкодження легеневої тканини [62].

\section{Механізм розвитку гіперкоагуляції та тромбозу при ендотеліальній дисфункції та COVID-19}

Непошкоджений ендотелій підтримує свою антитромбогенність, виділяючи глікокалікс та білок антитромбін. Пошкоджені ендотеліальні клітини змінюють свої властивості на прокоагулянтні внаслідок порушення глікокаліксу та втрати антикоагулянтних білків [49].

Активований прокоагулянтними чинниками запальний процес в ендотелії значно підвищує активність VWF, який починає виділятися із тіл Вейбеля - Палада, розташованих в ендотеліальних клітинах. VWF — глікопротеїн, який створює так звані містки між тромбоцитами та судинною стінкою і здатний активувати тромбоцити, що призводить до їх агрегації. Також він $\epsilon$ носі$\epsilon$ VIII фактора згортання крові і, як наслідок, сприяє згортанню крові, регулює ангіогенез та проникність судин [2, 18, 63].

vWF за нормальних умов розщеплюється протеазою ADAMTS13, але при тяжких запальних станах чи системній вірусній інфекції виникає її дефіцит, що призводить до підвищеного рівня VWF [27]. Також прискорюється виділення антигену VWF i фактора VIII, що посилює протромботичні процеси [26].

Окрім того, пошкоджений ендотеліальний шар клітин знижує експресію інших антикоагулянтів, таких як протеїн С та інгібітор тканинного фактора, що, в свою чергу, ще більше посилює прокоагулянтний ефект [17, 45].

При порушеній функції ендотеліальних клітин вони починають секретувати у підвищеній кількості PAl, який обмежує фібриноліз та знижує виділення tPA [45]. t-PA запобігає зв'язуванню тромбоцитів та знижує ініціацію каскаду згортання крові [45]. Внаслідок цього профібринолітичні функції ендотелію переходять в антифібринолітичні [45].

Коагулопатії та дисеміноване внутрішньосудинне згортання крові часто відмічають у тяжкохворих пацієнтів із SARS-CoV-2. При цьому має місце підвищення рівня D-димеру - продукту розпаду фібрину та фібриногену, що свідчить про те, що суттю коагулопатій при COVID-19 є підвищене утворення фібрину. При COVID-19 подовження протромбінового та активованого часткового тромбопластинового часу, зниження антитромбіну та тромбоцитів виявляють значно рідше порівняно з коагулопатіями, які відмічають при сепсисі та синдромі дисемінованого внутрішньосудинного згортання крові [49].

Низький рівень тромбоцитів тісно пов'язаний із тяжкістю захворювання та смертністю при COVID-19. Однією з причин зниження їх кількості $\epsilon$ збільшення в організмі кількості циркулюючих біомаркерів, таких як D-димер, Р-селектин та vWF. Ці речовини безпосередньо зв'язуються з тромбоцитами, спричиняючи їх гіперактивацію та агрегацію. Під час такої гіперактивації кількість тромбоцитів нижча через те, що гіперактивовані та агреговані тромбоцити не враховуються під час аналізу кількості тромбоцитів [63]. У пацієнтів із COVID-19 із середнім ступенем тяжкості кількість тромбоцитів, навпаки, вище норми. Отже, при COVID-19 рівень тромбоцитів може залежати від тяжкості захворювання [49].

Підвищення розчинного Р-селектину може не тільки відображати активацію тромбоцитів, а й активацію та пошкодження ендотелію [64]. Різні чинники пошкодження ендотеліальних клітин зумовлюють вивільнення Р-селектину у напрямку до апікальної мембрани ендотелію. Р-селектин також виділяється із а-гранул 
тромбоцитів в процесі їх дегрануляції $[45,63]$. Надмірний рівень розчинного Р-селектину в поєднанні з Е-селектином сприяє адгезії лейкоцитів до ендотелію. Розчинний Р-селектин циркулює як мономер, і для того щоб викликати адгезію лейкоцитів до судинної стінки, він повинен димеризуватися. Димеризований Р-селектин адгезує лейкоцити до ICAМ-1 і фібриногену, спричиняючи при цьому вивільнення гістонів та утворення NET [65]. Окрім цього, нейтрофіли, які циркулюють з Р-селектином, здатні вивільняти цитокін онкостатин М, який впливає на рецептори ендотеліальних клітин через глікопротеїн 130, призводить до скупчення Р-селектину і, як наслідок, до посиленої адгезії [45, 63].

Пригнічення антикоагулянтних властивостей ендотелію у хворих із COVID-19 призводить до протромботичного стану i, як наслідок, до оклюзії та утворення мікротромбів [7, 26, 54]. Хоча немає жодних відомостей про взаємозв'язок між COVID-19 та утворенням аневризми, але описано випадки, коли при існуючих аневризмах може бути прискорене тромбоутворення [66, 67]. Вищезазначене дає підстави для застосування в терапевтичних цілях при COVID-19 антикоагуляційних методів лікування [26, 54]. Цікаво, що гепарин виконує протизапальні функції шляхом зв'язування 3 запальними цитокінами, інгібування хемотаксису нейтрофілів та міграції лейкоцитів через ендотелій, нейтралізації позитивно зарядженого фактора комплементу пептиду С5а та секвестрування білків гострої фази $[26,68]$. Гепарин також може виступати антагоністом гістонів і таким чином захищати ендотелій [69].

У пацієнтів із COVID-19 може розвиватися як артеріальний (інсульт, інфаркт міокарда), так і венозний тромбоз (тромбоз глибоких вен, тромбоемболія легень, тромбоз венозних синусів) [17]. Спостерігається також підвищена тенденція до утворення плацентарних тромбозів у вагітних, які хворіли на COVID-19. R.N. Baergen, D.S. Heller (2020) показано, що тромбоз виявлено у 10 з 20 жінок [50]. Одну з основних ролей в утворенні тромбів при COVID-19 відіграє активація тромбоцитів. Коли відбувається пошкодження стінки судин, тканинний фактор стимулює синтез колагену і тромбіну. Ці речовини діють на ділянки, що містяться в субендотелії та запускають процес утворення тромбу. Адгезія тромбоцитів у місці пошкодження відбувається внаслідок взаємодії глікопротеїну VI з колагеном пошкодженої стінки судин та 3 тромбоцитарним глікопротеїном Ib-V-IX, який зв'язується 3 VWF. Активація тромбоцитів виникає після цієї взаємодії. Активовані тромбоцити здатні вивільняти хемокіни, такі як CXCL1, фактор тромбоцитів-4, CXCL5, CXCL7, CCL3, RANTES та CCL7, що посилюють активацію лейкоцитів. Іншим шляхом взаємодії тромбоцитів із лейкоцитами $\epsilon$ зв'язування Р-селектину з його спорідненим рецептором PSGL-1 на лейкоцитах $[31,70]$.

Взаємодія GP-Ib на тромбоцитах з Мас-1 на моноцитах і нейтрофілах призводить до їх активації [31]. Зв'язування GPIlb/llla, які розташовані на тромбоцитах, з SLC44A2/CTL-2 на нейтрофілах також спричиняє активацію тромбоцитів [31]. Більше того, не маючи ядра, тромбоцити експресують MPHK IL-1 $\beta$, яка може транслюватися як зрілий IL-1 $\beta$ [71].

Додаткова активація тромбоцитів відбувається за допомогою аденозиндифосфату та іонів кальцію, які вивільняються зі щільних гранул та діють через два рецептори аденозиндифосфату - Р2Y1 та Р2Y12. Виділення цих речовин, у свою чергу, виникає під впливом вже активованих тромбоцитів [72].

Поліфосфат (polyP), який вивільняється тромбоцитами, активує контактний шлях та через HMGB-1 (high-mobility group protein B1) підсилює активацію моноцитів, які здатні виділяти моноцитарний тканинний фактор [31]. Прозапальні стани, такі як інфекції, також стимулюють активацію внутрішньосудинного вивільнення тканинного фактору моноцитів [73]. Усі ці процеси посилюють вироблення тромбіну [31].

На сьогодні $\epsilon$ безліч доказів, що SARS-CoV-2 може безпосередньо взаємодіяти з тромбоцитами. Внаслідок цього посилюється їх тромботична та запальна функція [74]. Вірус грипу, як і SARS-CoV-2, $є$ одноланцюговим PHК-вірусом, який активує тромбоцити через TLR-7. Активація тромбоцитів TLR-7 вірусною PHK може викликати певний ряд реакцій, які спрямовані на утворен- ня тромбу [74, 75]. Це відбувається завдяки дегрануляції тромбоцитів та утворенню агрегатів тромбоцитів-лейкоцитів, що, в свою чергу, стимулює утворення NET [74, 75]. Не виключено, що SARS-CoV-2 має схожий механізм дії.

Усі вищезазначені механізми призводять до надмірного утворення тромбіну, який підсилює активацію тромбоцитів, лейкоцитів та ендотелію через протеазаактивовані рецептори [31]. Активація ендотелію внаслідок впливу тромбіну через протеазаактивований рецептор-1 спричиняє синтез прозапальних цитокінів та хемокінів та водночас викликає експресію ICAM-1 та Р-селектину [76, 77].

\section{Висновок}

Ендотеліальна дисфункція - важливий патогенетичний механізм розвитку COVID-19. АПФ-2-рецептори відіграють основну роль у проникненні SARS-CoV-2 в організм людини. «Цитокіновий шторм», активація комплементу та гіперкоагулятивні процеси запускають механізми розвитку ендотеліальної дисфункції. Цукровий діабет, гіпертонічна хвороба, ожиріння підвищують ступінь ендотеліальної дисфункції, що $\epsilon$ причиною тяжчого перебігу COVID-19. Всебічне вивчення ролі ендотеліальної дисфункції у механізмах розвитку COVID-19 полегшить розуміння патогенезу цього захворювання і дасть змогу запобігти ускладненням та високій смертності.

\section{Зв'язок роботи з науковими програмами}

Робота виконана у рамках держбюджетної науково-дослідної роботи «Ендотеліальна дисфункція, гіперкоагуляція та мікросудинний тромбоз при COVID-19: оцінка ризику, патогенез та діагностика» (2021-2023 рр., № держреєстрації 0121U100305).

\section{Connection with scientific programs}

The work was performed within the framework of the state budget research «Endothelial dysfunction, hypercoagulation and microvascular thrombosis in COVID-19: risk assessment, pathogenesis and diagnostics» (2021-2023, № state registration 0121U100305).

\section{Список використаної літератури/References:}

1. Khan A.A., Thomas G.N., Lip G.Y.H., Shantsila A. (2020) Endothelial function in patients with atrial fibrillation. Annals of Medicine, 52(1-2): 1-11. doi.org/10.1080/07853890.2019.171 1158

2. Ataman 0.V. (2018) Pathophysiology. In 2 vol. New book, Vinnytsia (nk.in.ua/pdf/1621.pdf). (In Ukr.).

3. Shevchuk V.G., Moroz V.M., Belan S.M. et al. (2012) Physiology. New book, Vinnytsia (chmnu. edu.ua/wp-content/uploads/2016/07/za-red.-V.G.SHevchuka-Fiziologiya.pdf). (In Ukr.).

4. Chhabra N. (2009) Endothelial dysfunction — A predictor of atherosclerosis. Internet Journal of Medical Update, 4(1): 33-41. www.geocities.com/agnihotrimed.

5. Förstermann U., Sessa W.C. (2012) Nitric oxide synthases: Regulation and function. Eur. Heart J., 33(7): 829-837. doi.org/10.1093/eurhearti/ehr304.

6. Michel J. (1998) Role of endothelial nitric oxide in the regulation of the vasomotor system (pubmed.ncbi.nlm.nih.gov/9769914/).

7. Colantuoni A., Martini R., Caprari P. et al. (2020) COVID-19 Sepsis and Microcirculation Dysfunction. Frontiers in Physiology, 11: 747. doi.org/10.3389/fphys.2020.00747.

8. Ritter A., Kreis N.N., Louwen F., Yuan J. (2020) Obesity and covid-19: Molecular mechanisms linking both pandemics. Int. J. Mol. Sci., 21(16): 1-28. doi.org/10.3390/ijms21165793.

9. Zhao Y., Vanhoutte P.M., Leung S.W.S. (2015) Vascular nitric oxide: Beyond eNOS. J. Pharm. Sci., 129(2): 83-94. doi.org/10.1016/j.jphs.2015.09.002.

10. Gewaltig M.T., Kojda G. (2002) Vasoprotection by nitric oxide: mechanisms and therapeutic potential. Cardiovasc. Res., 55(2): 250-260. doi.org/10.1016/50008-6363(02)00327-9.

11. Koyama Y. (2013) Endothelin systems in the brain: Involvement in pathophysiological responses of damaged nerve tissues. Biomolecular Concepts, 4(4):335-347. doi.org/10.1515/ bmc-2013-0004.

12. Jung F., Krüger-Genge A., Franke R.P. et al. (2020) COVID-19 and the endothelium. Clin. Hemorheol. Microcirc., 75(1): 7-11. doi.org/10.3233/CH-209007.

13. Rajendran P., Rengarajan T., Thangavel J. et al. (2013) The vascular endothelium and human diseases. Int. J. Biol. Sci., 9(10): 1057-1069. doi.org/10.7150/ijbs.7502.

14. Korakas E., Ikonomidis I., Kousathana F. et al. (2020) Obesity and COVID-19: immune and metabolic derangement as a possible link to adverse clinical outcomes. Am. J. Physiol. Endocrinol. Metabol., 319(1):E105-E109. doi.org/10.1152/ajpendo.00198.2020. 
15. Carfora V., Spiniello G., Ricciolino R. et al. (2020) Anticoagulant treatment in COVID-19: a narrative review. J. Thrombosis Thrombolysis, 1-7. doi.org/10.1007/s11239-020-02242-0.

16. Babushkina A.V. (2009) L-Arginine from an Evidence-Based Medicine Perspective. UMJ, 74(6): 43-48.

17. Ahmed S., Zimba 0., Gasparyan A.Y. (2020) Thrombosis in Coronavirus disease 2019 (COVID-19) through the prism of Virchow's triad. Clin. Rheumatol, 39: 2529-2543. doi.org/10.1007/ s10067-020-05275-1.

18. Amraei R., Rahimi N. (2020) COVID-19, Renin-Angiotensin System and Endothelial Dysfunction. Cells, 9(7): 1652. doi.org/10.3390/cells9071652.

19. Jothimani D., Venugopal R., Abedin M.F. et al. (2020) COVID-19 and the liver. J. Hepatol., 73(5): 1231-1240. doi.org/10.1016/j.jhep.2020.06.006.

20. Huang C., Wang Y., Li X. et al. (2020) Clinical features of patients infected with 2019 nove coronavirus in Wuhan, China. The Lancet, 395(10223): 497-506. doi.org/10.1016/S01406736(20)30183-5.

21. bestmaps.ru/COVID19

22. Varga Z., Flammer A.J., Steiger P. et al. (2020) Endothelial cell infection and endotheliitis in COVID-19. The Lancet, 395(10234): 1417-1418. doi.org/10.1016/S0140-6736(20)30937-5.

23. Amraie R., Napoleon M.A., Yin W. et al. (2020) CD209L/L-SIGN and CD209/DC-SIGN act as receptors for SARS-CoV-2 and are differentially expressed in lung and kidney epithelial and endothelial cells. BioRxiv, 1-25. doi.org/10.1101/2020.06.22.165803.

24. Cantuti-Castelvetri L., 0jha R., Pedro L.D. et al. (2020) Neuropilin-1 facilitates SARS-CoV-2 cell entry and infectivity. Science, 370(6518): 856-860. doi.org/10.1126/science.abd2985.

25. Kipshidze N., Dangas G., White C.J. et al. (2020) Viral Coagulopathy in Patients With COVID-19: Treatment and Care. Clin. Appl. Thromb. Hemost., 26: 1-7. doi.org/10.1177/1076029620936776.

26. Pons S., Fodil S., Azoulay E., Zafrani L. (2020) The vascular endothelium: The cornerstone of organ dysfunction in severe SARS-CoV-2 infection. Critical Care, 24(353): 1-8. doi.org/10.1186/s13054020-03062-7.

27. Del Turco S., Vianello A., Ragusa R. et al. (2020) COVID-19 and cardiovascular consequences: Is the endothelial dysfunction the hardest challenge? Thromb. Res., 196: 143-151. doi.org/10.1016/j. thromres.2020.08.039.

28. Yan R., Zhang Y., LiY. et al. (2020) Structural basis for the recognition of SARS-CoV-2 by full-length human ACE2. Science, 367(6485): 1444-1448. doi.org/10.1126/science.abb2762.

29. Hoffmann M., Kleine-Weber H., Schroeder S. et al. (2020) SARS-CoV-2 Cell Entry Depends on ACE2 andTMPRSS2 and Is Blocked by a Clinically Proven Protease Inhibitor.Cell, 181:271-280. doi. org/10.1016/j.cell.2020.02.052

30. Iwata-Yoshikawa N., Okamura T., Shimizu Y. et al. (2019) TMPRSS2 Contributes to Virus Spread and Immunopathology in the Airways of Murine Models after Coronavirus Infection. J. Virol., 93(6): 1815-1833. doi.org/10.1128/jvi.01815-18.

31. McFadyen J.D., Stevens H., Peter K. (2020) The Emerging Threat of (Micro)Thrombosis in COVID-19 and Its Therapeutic Implications. Circ. Res., 127(4): 571-587. doi.org/10.1161/CIRCRESAHA.120.317447.

32. Su H., Yang M., Wan C. et al. (2020) Renal histopathological analysis of 26 postmortem findings of patients with COVID-19 in China. Kidney Int.,98(1):219-227. doi.org/10.1016/j.kint.2020.04.003.

33. Hamming l., TimensW., Bulthuis M. et al. (2004) Tissue distribution of ACE2 protein, the functional receptor for SARS coronavirus. A first step in understanding SARS pathogenesis. J. Pathol., 203(2): 631-637. doi.org/10.1002/path.1570.

34. Leisman D.E., Deutschman C.S.,Legrand M. (2020) Facing COVID-19 in the ICU:vascular dysfunction, thrombosis, and dysregulated inflammation. Intens. CareMed., 46(6):1105-1108. doi.org/10.1007/ s00134-020-06059-6.

35. Alharthy A., Faqihi F., Memish Z.A., Karakitsos D. (2020) Fragile Endothelium and Brain Dysregulated Neurochemical Activity in COVID-19. ACS Chemical Neuroscience, 11(15): 2159-2162. doi.org/10.1021/acschemneuro.0c00437.

36. Nishimura H., Tsuji H., Masuda H. et al. (1997) Angiotensin Il increases plasminogen activator inhibitor- 1 and tissue factor mRNA expression without changing that of tissue type plasminogen activator or tissue factor pathway inhibitor in cultured rat aortic endothelial cells. Thromb. Haemost., 77(6): 1189-1195. doi.org/10.1055/s-0038-1656136.

37. Yang J., Zheng Y., Gou X. et al. (2020) Prevalence of comorbidities and its effects in coronavirus disease 2019 patients: A systematic review and meta-analysis. Int. J. Infect. Dis., 94: 91-95. doi.org/10.1016/j.ijid.2020.03.017.

38. Zhang J., Dong X., Cao Y. et al. (2020) Clinical characteristics of 140 patients infected with SARS-CoV-2 in Wuhan, China. Allergy, 75(7): 1730-1741. doi.org/10.1111/all.14238

39. Henry B.M., Vikse J., Benoit S. et al. (2020) Hyperinflammation and derangement of reninangiotensin-aldosterone system in COVID-19: A novel hypothesis for clinically suspected hypercoagulopathy and microvascular immunothrombosis. Clin. Chim. Acta, 507: 167-173. doi.org/10.1016/j.cca.2020.04.027.

40. Oudit,. G.Y., Kassiri Z., Jiang C. et al. (2009) SARS-coronavirus modulation of myocardial ACE2 expression and inflammation in patients with SARS. Eur. J. Clin. Invest., 39(7): 618-625. doi.org/10.1111/j.1365-2362.2009.02153.x.
41. Gustafson D., Raju S., Wu R. et al. (2020) Overcoming barriers: The endothelium as a linchpin of coronavirus disease 2019 pathogenesis? Arteriosclerosis, Thrombosis, and Vascular Biology, 40(8): 1818-1829. doi.org/10.1161/ATVBAHA.120.314558.

42. Moccia F., Gerbino A., Lionetti V. et al. (2020) COVID-19-associated cardiovascular morbidity in older adults: a position paper from the Italian Society of Cardiovascular Researches. GeroScience, 42(4): 1021-1049. doi.org/10.1007/s11357-020-00198-w.

43. Endemann D.H., Schiffrin E.L. (2004) Endothelial dysfunction. Journal of the American Society of Nephrology, 15(8): 1983-1992. doi.org/10.1097/01.ASN.0000132474.50966.

44. Nimrichter L., Burdick M.M., Aoki K. et al. (2008) E-selectin receptors on human leukocytes. Blood, 112(9): 3744-3752. doi.org/10.1182/blood-2008-04-149641.

45. Page A.V., Liles W.C. (2013) Biomarkers of endothelial activation/dysfunction in infectious diseases. Virulence, 4(6): 507-516. doi.org/10.4161/viru.24530.

46. Channappanavar R., Perlman S. (2017) Pathogenic human coronavirus infections: causes and consequences of cytokine storm and immunopathology. Semin. Immunopathol., 39(5): 529-539. doi.org/10.1007/s00281-017-0629-x.

47. Chen G., Wu D., Guo W. et al. (2020) Clinical and immunological features of severe and moderate coronavirus disease 2019. J. Clin. Invest., 130(5): 2620-2629. doi.org/10.1172/ JCl137244.

48. Moore J.B., June C.H. (2020) Cytokine release syndrome in severe COVID-19. Science, 368(6490): 473-474. science.sciencemag.org/content/368/6490/473.summary.

49. Iba T., Levy J.H., Levi M., Thachil J. (2020) Coagulopathy in COVID-19. J. Thromb. Haemost., 18(9): 2103-2109. doi.org/10.1111/jth.14975

50. Baergen R.N., Heller D.S. (2020) Placental Pathology in Covid-19 Positive Mothers: Preliminary Findings. Pediatr. Devel. Pathol., 23(3): 177-180. doi. org/10.1177/1093526620925569.

51. Tyagi N., Roberts A.M., Dean W.L. et al. (2008) Fibrinogen induces endothelial cell permeability. Mol. Cel. Biochem., 307(1-2): 13-22. doi.org/10.1007/s11010-007-9579-2.

52. Lawson C., Wolf S. (2009) ICAM-1 signaling in endothelial cells. Pharmacological Reports, 61(1): 22-32. doi.org/10.1016/S1734-1140(09)70004-0.

53. Lominadze D., Tsakadze N., Sen U. et al. (2005) Fibrinogen and fragment D-induced vascular constriction. Am. J. Physiol. Heart Circul. Physiol., 288(3): H1257-H1264. doi.org/10.1152/ ajpheart.00856.2004.

54. Takano S., Kimura S., Ohdama S., Aoki N. (1990) Plasma Thrombomodulin in Health and Diseases. Blood, 76(10): 2024-2029. ashpublications.org/blood/articlepdf/76/10/2024/603283/2024.pdf.

55. Noris M., Benigni A., Remuzzi G. (2020) The case of complement activation in COVID-19 multiorgan impact. Kidney Int., 98(2): 314-322. doi.org/10.1016/j.kint.2020.05.013.

56. Foreman K.E., Vaporciyan A.A., Bonish B.K. et al. (1994) C5a-induced expression of P-selectin in endothelial cells. J. Clin. Invest., 94: 1147-1155. doi.org/10.1172/JCI117430.

57. de Bont C.M., BoelensW.C.,Pruijn G.J.M. (2019) NETosis, complement, and coagulation: a triangular relationship. Cel. Molec. Immunol., 16: 19-27. doi.org/10.1038/s41423-018-0024-0.

58. Marchetti M. (2020) COVID-19-driven endothelial damage: complement, HIF-1, and ABL2 are potential pathways of damage and targets for cure. Ann. Hematol.,99:1701-1707.doi.org/10.1007/ s00277-020-04138-8.

59. Ritis K., Doumas M., Mastellos D. et al. (2006) A Novel C5a Receptor-Tissue Factor Cross-Talk in Neutrophils Links Innate Immunity to Coagulation Pathways. J. Immunol., 177(7): 4794-4802. doi. org/10.4049/jimmunol.177.7.4794.

60. Platt J.L., Dalmasso A.P., Lindman B.J. et al. (1991) The role of C5a and antibody in the release of heparan sulfate from endothelial cells. Eur. J. Immunol., 21(11): 2887-2890. doi.org/10.1002/ eji. 1830211135

61. Magro C., Mulvey J.J., Berlin D. et al. (2020) Complement associated microvascular injury and thrombosis in the pathogenesis of severe COVID-19 infection: A report of five cases. Translat. Res., 220: 1-13. doi.org/10.1016/j.trsl.2020.04.007.

62. Risitano A.M., Mastellos D.C., Huber-Lang M. et al. (2020) Complement as a target in COVID-19? Nature Rev. Immunol., 20:343-344. doi.org/10.1038/s41577-020-0320-7.

63. GroblerC.,Maphumul0S.C.,GrobbelaarL.M.etal.(2020) Covid-19:The Rollercoaster ofFibrin(Ogen), D-Dimer, Von Willebrand Factor, P-Selectin and Their Interactions with Endothelial Cells, Platelets and Erythrocytes. Int. J. Mol. Sci., 21(14): 5168. doi.org/10.3390/ijms21145168.

64. PawelczykM., Glabiński A., Kaczorowska B., BajZ. (2018) sP-and sE-selectin in stroke patients with metabolic disorders. Neurol. Neurochi. Polska,52:599-605. doi.org/10.1016/j.pjnns.2018.08.004.

65. Gross P. L. (2017) Soluble P-selectin is the smoke, not the fire. Blood, 130(2): 101-102. doi. org/10.1182/blood-2017-05-786319.

66. Rinaldi L.F., Marazzi G., Marone E.M. (2020) Endovascular Treatment of a Ruptured Pararenal Abdominal Aortic Aneurysm in a Patient With Coronavirus Disease-2019: Suggestions and Case Report. Ann. Vasc. Surg., 66: 18-23. doi.org/10.1016/j.avsg.2020.05.011.

67. Shih M., Swearingen B., Rhee R. (2020) Ruptured Abdominal Aortic Aneurysm Treated with Endovascular Repair in a Patient with Active COVID-19 Infection during the Pandemic. Ann. Vasc. Surg., 66: 14-17. doi.org/10.1016/j.avsg.2020.05.001. 
68. Mousavi S., Moradi M., Khorshidahmad T., Motamedi M. (2015) Anti-inflammatory effects of heparin and its derivatives: A systematic review. Adv. Pharmacol. Sci.: 1-14. doi. org/10.1155/2015/507151.

69. Zhu C., Liang Y., Li X. et al. (2019) Unfractionated heparin attenuates histone-mediated cytotoxicity in vitro and prevents intestinal microcirculatory dysfunction in histone-infused rats. J. Trauma Acute Care Surg., 87(3): 614-622. doi.org/10.1097/TA.0000000000002387.

70. Furie B., Furie B.C. (2008) Mechanisms of Thrombus Formation. New Engl. J. Med., 359: 938-949. doi.org/10.1056/NEJMra0801082.

71. Lindemann S., Tolley N.D., Dixon D.A. etal. (2001) Activated platelets mediate inflammatory signaling by regulated interleukin $1 \beta$ synthesis. J. Cell Biol., 154(3): 485-490. doi.org/10.1083/ jcb.200105058.

72. Davi G., Patrono C. (2007) Platelet Activation and Atherothrombosis. New Engl. J. Med., 357(24): 2482-2494. doi.org/10.1056/NEMMra071014.

73. Jayarangaiah A., Kariyanna P.T., Chen X. etal. (2020) COVID-19-Associated Coagulopathy: An Exacerbated Immunothrombosis Response. Clin. Appl. Thromb. Hemost., 26: 1-11. doi. org/10.1177/1076029620943293.

74. Assinger A. (2014) Platelets and infection - An emerging role of platelets in viral infection. Front. Immunol., 5(649): 1-12. doi.org/10.3389/fimmu.2014.00649.

75. Koupenova M., Corkrey H.A.,V Vitseva 0 . et al. (2019) The role of platelets in mediating a response to human influenza infection. Nature Commun., 10(1780): 1-18. doi.org/10.1038/541467-01909607-x.

76. Chen D., Carpenter A.,Abrahams J. etal. (2008) Protease-activated receptor 1 activation is necessary for monocyte chemoattractant protein 1-dependent leukocyte recruitment in vivo. J. Experiment. Med., 205(8): 1739-1746. doi.org/10.1084/jem.20071427.

77. Sugama Y., Tiruppathi C., Janakidevi K. et al. (1992) Thrombin-induced expression of endothelial P-selectin and intercellular adhesion molecule-1:A mechanism for stabilizing neutrophil adhesion. J. Cell Biol., 119(4): 935-944. doi.org/10.1083/jcb.119.4.935.

\section{Endothelial dysfunction in COVID-19 (literature review)}

A.I. Pak, O.O. Shevchuk, S.M. Paliy, B.P. Selskiy, M.M. Korda

I. Horbachevsky Ternopil National Medical University, Ternopil, Ukraine

Abstract. It has been repeatedly confirmed that the virus SARS-CoV-2 the cause of a pandemic COVID-19 worldwide - is involved in the development or aggravation of existing endothelial dysfunction. The main route of penetration of the virus into the human body are ACE2 receptors, which are expressed, including on endothelial cells. Once in the host cells, SARS-CoV-2 stimulates the processes of local inflammation, as a result of which cytokines begin to be intensively released, which in turn also have a negative effect on the endothelium. The cytokine stormactivated complement pathways lead to even greater synthesis of cytokines, as well as increased production of adhesion molecules. The inflammatory process in endothelial cells stimulates procoagulant, prothrombotic and antifibrinolytic factors that adversely affect the blood coagulation process. In addition, excessive synthesis of vasoconstrictor factors by activated endothelium promotes hypercoagulated processes in the body. The article discusses the main mechanisms for the development of endothelial dysfunction in COVID-19. Understanding the pathogenesis of this pathology will make it possible to identify certain aspects of treatment and prevention of complications in patients with COVID-19, which will help to cope with complications and high mortality from this disease.

Key words: COVID-19, endothelial dysfunction, cytokines, hemostasis.

\section{Відомості про авторів:}

ПакАнастасія Іванівна — аспірантка, кафедра медичної біохімії, Тернопільський національний медичний університет імені І.Я. Горбачевського М0зУкраїни, Тернопіль, Україна.

Шевчук Оксана Олегівна — доктор медичних наук, доцент кафедри фармакології з клінічною фармакологією Тернопільського національного медичного університету імені І.Я. Горбачевського М0зУкраїни, Тернопіль, Україна. Палій Світлана Михайлівна — студентка VI курсу Тернопільського національного медичного університету імен І.Я. Горбачевського МОз України, Тернопіль, Україна.

Сельський Борислав Петрович — аспірант кафедри хірургії № 2 Тернопільського національного медичного університету імені І.Я. Горбачевського М0зУкраїни, Тернопіль, Україна.

Корда Михайло Михайлович — доктор медичних наук, професор кафедри медичної біохімії Тернопільського національного медичного університету імені І.Я. Горбачевського М0З України, Тернопіль, Україна.

Адреса для кореспонденції:

ПакАнастасія Іванівна

46002, Тернопіль, майдан Волі, 1

E-mail:pak_aniv@tdmu.edu.ua

\section{Information about the authors:}

Pak Anastasia I.- PhD student, Department of Medical Biochemistry, I. Horbachevsky Ternopil National Medical University, Ternopil, Ukraine.

Shevchuk Oksana 0. - MD, Ph.D., DSc, Ass-prof., Department of Pharmacology and Clinical Pharmacology, Ternopil National Medical University, Ternopil, Ukraine. Paliy Svitlana M. $-6^{\text {th }}$ year student, Ternopil National Medical University, Ternopil, Ukraine.

Selskiy Borislav P. — PhD student, Department of Surgery № 2, Ternopil National Medical University, Ternopil, Ukraine.

Korda Mykhailo M. - MD, Ph.D., DSc, Prof., Department of Medical Biochemistry, I. Horbachevsky Ternopil National Medical University, Ternopil, Ukraine.

Address for correspondence:

Anastasia Pak

46002, Ternopil, Freedom Square, 1

E-mail:pak_aniv@tdmu.edu.ua

Надійшла до редакції/Received: 21.05.2021 Прийнято до друку/Accepted: 16.06.2021 